\title{
NMR metabolite comparison of local pigmented rice in Yogyakarta
}

\author{
Dio Nardo Wijaya ${ }^{1}$, Febri Adi Susanto ${ }^{2}$, Yekti Asih Purwestri ${ }^{1,2}$, Dyah Ismoyowati ${ }^{3}$, and Tri Rini Nuringtyas ${ }^{1,2, *}$ \\ ${ }^{1}$ Faculty of Biology, Universitas Gadjah Mada, Jalan Teknika Selatan, Sekip Utara, Yogyakarta 55281, Indonesia \\ ${ }^{2}$ Research Center for Biotechnology, Universitas Gadjah Mada, Depok, Sleman, Yogyakarta 55281, Indonesia \\ ${ }^{3}$ Agricultural Technology, Universitas Gadjah Mada, Jalan Socia Justicia Bulaksumur, Yogyakarta 55281, Indonesia \\ *Corresponding author: tririni@ugm.ac.id
}

\begin{abstract}
Pigmented rice may have a black or red color due to higher anthocyanin content in its grain. A natural antioxidant, many studies on anthocyanin have reported its positive effects on human health. This fact has spurred the development of pigmented rice as a functional food. This study aimed to compare the metabolite profiles of black and red rice. Three black rice cultivars, namely Melik, Pari Ireng, and Cempo Ireng Sleman, and two red rice cultivars, Inpari 24 and RC 204, were used. After husk removal, grain samples were ground in liquid nitrogen and dried with a freeze dryer. The dried samples were extracted using 50\% MeOD4 (in a $\mathrm{D}_{2} \mathrm{O}$ phosphate buffer $\mathrm{pH} 6$ containing $0.01 \%$ TSP as an internal standard). Metabolomic analysis was performed using $500 \mathrm{MHz}$ NMR followed by multivariate data analysis. An orthogonal partial least squares-discriminant analysis (OPLS-DA) model after PCA was constructed to discriminate between the five different cultivars. The resulting OPLS-DA score plot revealed a clear separation between black rice and red rice. The metabolites that could influence the separation of red rice and black rice were valine, threonine, alanine, glutamate, galactinol, $\beta$-glucose, $a$-glucose, raffinose, and fumaric acid.
\end{abstract}

KEYWORDS metabolite comparison; nuclear magnetic resonance (NMR); pigmented rice

\section{Introduction}

Rice Oryza sativa L. is one of the major nourishing cereal crops, and pigmented rice has been consumed for a long time in Asia, especially in Indonesia (Andoko 2012; Tananuwong and Tewaruth 2010). The most common rice consumed by human is white rice (about $85 \%$ ) and the rest is pigmented rice. The pigmented rice is mainly black, red and dark purple rice, which have dark red, dark purple, dark blue, red-brown, black purple, or dark red-purple grains (Asamarai et al. 1996). Pigmented rice or colored rice is distinguished by the rice grain having red-brown or dark purple color in its covering layers (Yawadio et al. 2007). Anthocyanins, a group of reddish to purple watersoluble flavonoids are considered as the major functional components of pigmented rice (Hyun and Chung 2004; Moreno et al. 2005; Mingwei et al. 2006).

Indonesia has been known to have a wide variety of local pigmented rice (Slamet-Loedin et al. 1997). The local pigmented rice is much developed in Yogyakarta (Kristamtini and Purwaningsih 2009). The black and red rice have been used as functional food, and their extracts are also used as a food colorant in bread, ice cream, and liquor (Yoshinaga et al. 1986). Recent studies demonstrated that pigmented rice had a wide range of biological activities, including amelioration of iron deficiency anemia of the body (Xu and Wang 1989; Chen et al. 2000), antioxidant (Ichikawa et al. 2001; Ling et al. 2001, 2002), anticarcinogenic, antiatherosclerosis, antiallergic activities (Matsumoto et al. 2003; Nam et al. 2006; Wang et al. 2007). Pigmented rice has also been known to have benefits in diabetic prevention (Yawadio et al. 2007). It also has been reported that aside from the color, these two type of pigmented rice also differ in their resistance to pest and pathogen (Ginanjar 2016; Wijaya 2017). It means that the pigmented rice exhibited the metabolites potentially related to defense mechanism against pathogen.

The benefits of pigmented rice depend on its metabolites. The metabolites in the plant have a high level of variation, including in pigmented rice. This is caused by several factors such as a gene, substrate specificity to some enzymes, subcellular compartment and non-enzymatic reactions (Hall et al. 2002). Pramai et al. (2017) reported there are profile metabolite differentiations between black rice and red rice cultivars in Thailand. The other research also showed differentiation of metabolites between black rice and red rice (Yawadio et al. 2007; Frank et al. 2012; Na Jom et al. 2016; Huang and Lai 2016). However, there is no information about metabolite profile differentiation between black rice and red rice in Indonesia. In Indone- 
sia, Yogyakarta is a region which has a wide variety of pigmented rice and comparison of local pigmented rice in Yogyakarta has not been investigated yet. This work aims to compare metabolite profile between black rice and red rice from local varieties in Yogyakarta.

\section{Materials and methods}

\subsection{Chemicals}

$\mathrm{KH}_{2} \mathrm{PO}_{4}$, 3-(trimethylsilyl)propionic-2,2,3,3- $\mathrm{d}_{4}$ acid sodium salt (TSP), methanol-d $\mathrm{d}_{4}\left(\mathrm{CD}_{3} \mathrm{OD}\right) 99.8 \%$, sodium deuteroxide (NaOD) 99.5\%, liquid nitrogen.

\subsection{Plant materials}

Rice cultivars of Melik, Pari Ireng, and Cempo Ireng Sleman were used as black rice group and Inpari 24 and RC 204 were used as red rice group. All of the cultivars were grown in screen house under natural condition and the grains were collected at 4-5 months after transplanting. The sample was ground in liquid nitrogen and dried with freeze dryer. The dried samples were stored at $4^{\circ} \mathrm{C}$.

\subsection{Extraction of plant materials}

The $50 \mathrm{mg}$ dried samples were used for NMR metabolomics. The dried samples were extracted using 50\% MeOD4 (in $\mathrm{D}_{2} \mathrm{O}$ phosphate buffer $\mathrm{pH} 6$ containing $0.01 \%$ TSP as an internal standard). The mixture was mixed by vortex at room temperature for $2 \mathrm{~min}$ and ultrasonicated for $15 \mathrm{~min}$. Subsequently, the mixture was centrifuged for $15 \mathrm{~min}$ at $13.000 \mathrm{rpm}$. An aliquot of $800 \mu \mathrm{L}$ of the supernatant was transferred to a $5 \mathrm{~mm}$ NMR tube.

\section{4. ${ }^{1} \mathrm{H}$-NMR analysis}

The ${ }^{1} \mathrm{H}$-NMR spectra were recorded at $25^{\circ} \mathrm{C}$ on a 500 MHz JEOL NMR Spectrometer (JEOL Inc., USA) operating at a proton NMR frequency of 500.13 MHz. Deuterated methanol was used as the internal lock. Each ${ }^{1} \mathrm{H}$ NMR spectra consisted of 128 scans requiring $10 \mathrm{~min}$ and $26 \mathrm{~s}$ acquisition. For each sample, a relaxation delay of $1.5 \mathrm{~s}$ was recorded. The preparation procedure was performed following the reported method (Kim et al. 2010) with some modifications. The TSP was used as a reference at $\delta 0.00$. The metabolites were identified based on the ${ }^{1} \mathrm{H}-\mathrm{NMR}$ spectra and comparisons with the NMR spectra of the reference compounds and published literatures (Fan 1996; Dai et al. 2010; Kim et al. 2010; Jones et al. 2011; Nuringtyas et al. 2012; Nam et al. 2015; Uawisetwathana et al. 2015; Liu et al. 2017; Pramai et al. 2017).

\subsection{The bucketing of ${ }^{1} \mathrm{H}$-NMR spectra and multivari- ate statistical analysis}

Phasing and baseline corrections were performed manually for all spectra using Mestrenova software version 11.0 (Escondido. CA, USA). The ${ }^{1} \mathrm{H}-\mathrm{NMR}$ spectra were reduced to text files. All spectral intensities were binned using a spectral width $(\delta 0.04)$ and forming a region of $\delta$ $-0.50-10.0$. The regions of $\delta 4.70-4.90$ and $\delta 3.23-3.36$, were excluded from the analysis due to the residual signals of water and methanol. In order to cluster the samples, Orthogonal Partial Least Square-Discriminant Analysis (OPLS-DA) was performed with SIMCA software (version 14.0, Umetrics, Umea, Sweden). Scaling was based on the Pareto method. OPLS-DA method was validated with CV-ANOVA method ( $\mathrm{p}$ value $<0.05$ ).

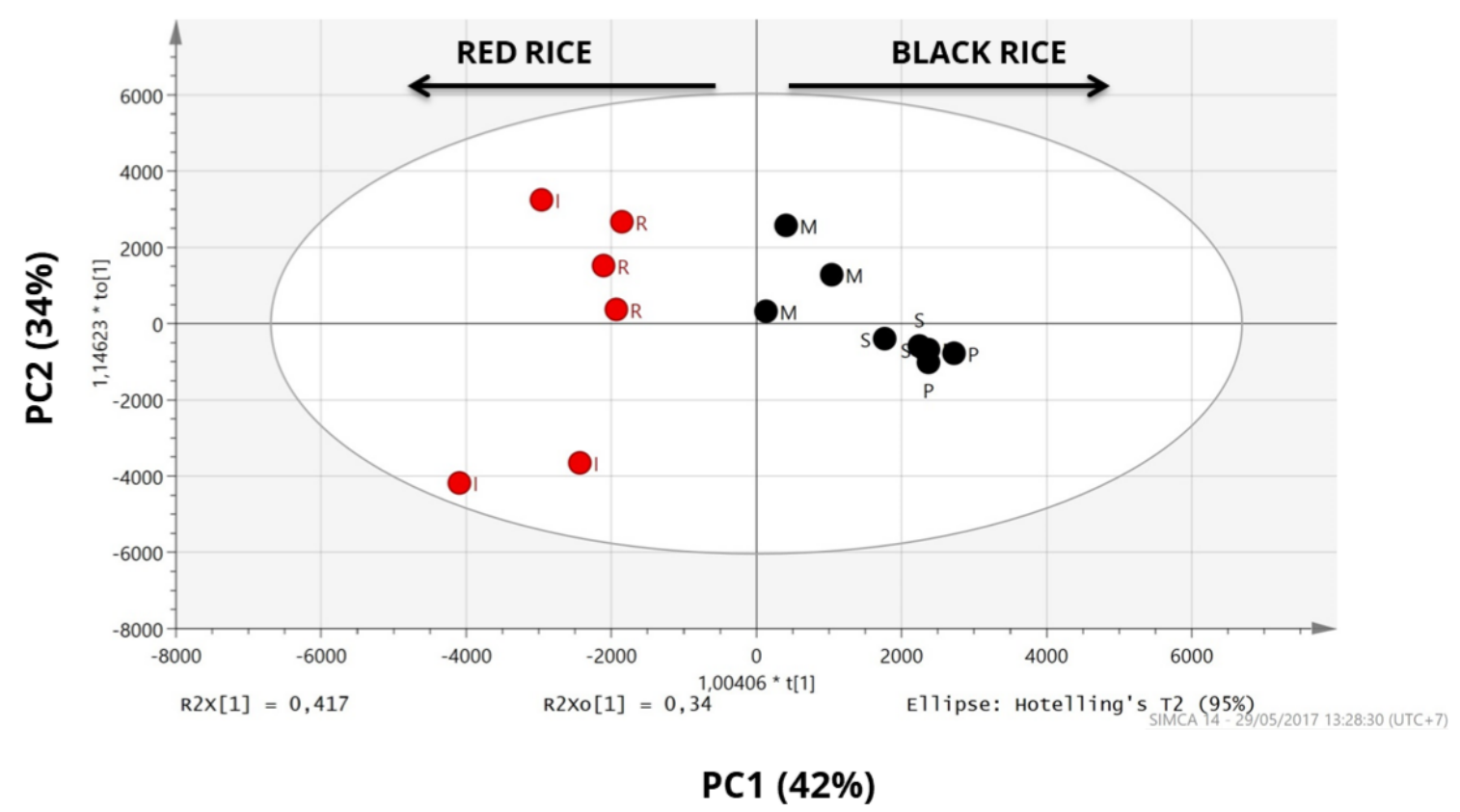

FIGURE 1 Score plot of OPLS-DA based on ${ }^{1} \mathrm{H}$ NMR signals of extracts from pigmented rice. 
TABLE $1{ }^{1} \mathrm{H}$ chemical shifts $(\delta)$ in metabolites of grains of black rice and red rice identified by $1 \mathrm{D}$ NMR spectra in $\mathrm{MeOD}_{4}$.

\begin{tabular}{lll}
\hline Group & Metabolite & Characteristic Signals in NMR \\
\hline Amino acid & Alanine & $\delta 1.46(\mathrm{~d}, J=7.0 \mathrm{~Hz})$ \\
& Glutamate & $\delta 2.10-2.16(\mathrm{~m}), \delta 1.98-2.06(\mathrm{~m})$ \\
& Threonine & $\delta 1.34(\mathrm{~d}, J=7.0 \mathrm{~Hz}), \delta 4.22(\mathrm{~m})$ \\
& Valine & $\delta 1.02(\mathrm{~d}, J=7.0 \mathrm{~Hz}), \delta 1.06(\mathrm{~d}, J=7.0 \mathrm{~Hz}), \delta 1.00(\mathrm{~d}, J=6.8 \mathrm{~Hz})$ \\
\hline Organic acid & Hydroxy-L-proline & $\delta 4.33-4.38(\mathrm{~m})$ \\
& Acetate & $\delta 1.90(\mathrm{~s})$ \\
& Succinic acid & $\delta 2.54(\mathrm{~s})$ \\
& Formic acid & $\delta 8.46(\mathrm{~s})$ \\
\hline Sugar & Fumaric acid & $\delta 6.53(\mathrm{~s})$ \\
& a-Glucose & $\delta 5.18(\mathrm{~d}, J=3.8 \mathrm{~Hz})$ \\
& $\beta$-Glucose & $\delta 4.58(\mathrm{~d}, J=7.8 \mathrm{~Hz})$ \\
& Galactinol & $\delta 3.97(\mathrm{~m})$ \\
\hline Others & Raffinose & $\delta 5.42(\mathrm{~d}, J=3.93 \mathrm{~Hz})$ \\
\hline
\end{tabular}

$\mathrm{d}=$ doublet; $\mathrm{m}=$ multiplet; $\mathrm{s}=$ singlet

\section{Results and discussion}

${ }^{1} \mathrm{H}$ NMR measurements of both red and black rice extracts allowed the identification of a number of different types of metabolites including amino acids, organic acids, sugars and others metabolites (Table 1). The identification of metabolites in pigmented rice was based on NMR spectra of known compounds acquired in previous studies on various plants (Fan 1996; Dai et al. 2010; Kim et al. 2010; Jones et al. 2011; Nuringtyas et al. 2012; Nam et al. 2015; Uawisetwathana et al. 2015; Liu et al. 2017; Pramai et al. 2017). The most intense signals within each ${ }^{1} \mathrm{H}$ NMR spectrum were primary metabolites that are detected in the $\delta 5.5-\delta 0.5 \mathrm{ppm}$. There were amino acids appear around $\delta$ $2.0-\delta 0.5 \mathrm{ppm}$, organic acids at $\delta 3.0-\delta 2.0 \mathrm{ppm}$ and sugars at $\delta 5.0-\delta 3.0 \mathrm{ppm}$.

The successfully identified metabolites were primary metabolites. This result was presumably due to the age of the collected rice grains. The rice grains were collected at the milky stage, an early stage of grain ripening during which the grain produces more primary metabolites used for growth development (Heldt and Heldt 2004).

Pigmented rice has been established as a functional food and its health benefits rely on a powerful method of obtaining high concentrations of bioactive compounds. Orthogonal partial least square regression-discriminant analysis (OPLS-DA) was introduced as an improvement over the partial least square discriminant analysis (PLSDA) in the discrimination of two or more classes using multivariate data (Bylesjö et al. 2006). The advantage of OPLS-DA compared with PLS-DA is that a single component is used as a predictor for the class, while the other components describe the variation orthogonal to the first predictive component (Westerhuis et al. 2010). To distinguish between metabolites from red rice and black rice in this study, PLS-DA analysis was extended to OPLS-DA.

The OPLS-DA analysis showed a clear separation between red rice and black rice (Figure 1). The model resulted in a variance $\mathrm{R}^{2}$ of 0.756 and a predictive ability $\mathrm{Q}^{2}$ of 0.731 . The cross-validation of the model using CVANOVA gave highly significant results $(\mathrm{F}=6.78, \mathrm{P}=$ 0.007). The loading plot of the OPLS-DA showed that signals of alanine, glutamate, threonine, valine, acetate, succinic acid, formic acid, fumaric acid, $\alpha$-glucose, $\beta$-glucose, galactinol, raffinose, and choline were present in the negative quadrant of PC1, which present red rice, and hydroxylL-proline and adenosine were present in the positive quadrant representing black rice (Figure 2).

The concentration of each metabolite was analyzed by one way ANOVA test to ensure the loading plot of OPLSDA. Based on one way ANOVA test, the metabolites that could influence the separation of red rice and black rice are valine ( $\mathrm{p}<0.05)$, threonine $(\mathrm{p}<0.05)$, alanine $(\mathrm{p}<0.05)$, glutamate $(\mathrm{p}<0.05)$, galactinol $(\mathrm{p}<0.05), \beta$-glucose $(\mathrm{p}<$ $0.01)$, $\alpha$-glucose ( $<<0.01)$, raffinose $(\mathrm{p}<0.018)$, and fumaric acid $(p<0.012)$. The significance of the metabolites can be seen more clearly in Figure 3.

The loading plot showed that red rice was separated due the higher content of some amino acids (alanine, glutamate, threonine, and valine), organic acids (acetate, succinic acid, formic acid and fumaric acid), sugars ( $\alpha$ glucose, $\beta$-glucose, galactinol, and raffinose) and choline than those in black rice. Primary metabolites such as amino acids and sugars besides being used for growth, is also known as a precursor of secondary metabolites (Heldt and Heldt 2004). 


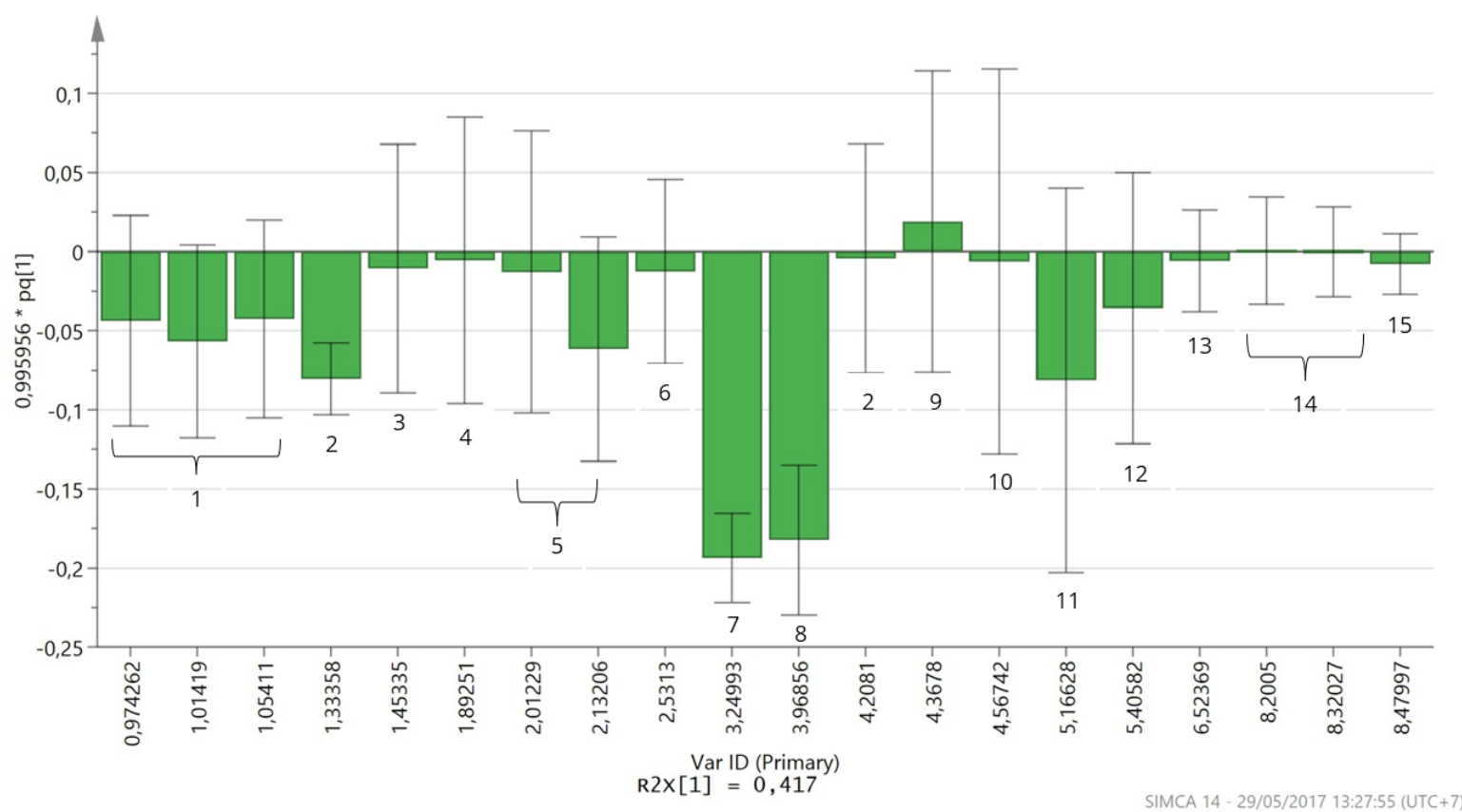

FIGURE 2 Loading plot of PLS-DA based on ${ }^{1} \mathrm{H}$ NMR signals of extracts from pigmented rice: 1, valine; 2 , threonine; 3 , alanine; 4, acetate; 5 , glutamate; 6 , succininc acid; 7 , choline; 8 , galactinol; 9 , hydroxy-I-proline; $10, \beta$-glucose; 11 , a-glucose; 12 , raffinose; 13 , fumaric acid; 14 , adenosine; 15 , formic acid.

Sugars such as glucose are recognized as signaling molecules in plants (Rolland et al. 2006; BolouriMoghaddam et al. 2010), in addition to their typical roles as carbon and energy sources (Koch 2004). Sugar signaling might also be of great importance in plant (defense) responses under biotic and abiotic stresses. Therefore, sugars from plant (Herbers et al. 1996) origin might play critical roles in host-pathogen interactions (Morkunas et al. 2005). Another sugar, galactinol is a precursor for the synthesis of raffinose (catalyzed by raffinose synthase). Evidence shows that galactinol and likely raffinose as well are involved as signals to stimulate plant immunity under pathogen attack. Indeed, external application of galactinol resulted in the activation of PR1a, PR1b, and NtACS1, which are well-known defense-related genes in tobacco (Kim et al. 2008). Raffinose is also known has functioned on induction of resistance against nematode infection (Hofmann et al. 2010). Galactinol and raffinose may have contributed to the resistance of pigmented rice against pathogen, although this study was limited to the measurements of metabolites with pathogen treatment.

Amino acids also have been considered to have an important role in defense response (Steinbrenner et al. 2011). Glutamate is a precursor for arginine, spermine, and $\gamma$-amino-butyric acid which were related to plant defense (Gill and Tuteja 2010; Huang et al. 2011; Kusano et al. 2015). Threonine has been conferred as the amino acid that resistant to Hyaloperonospora arabidopsilis, presumably by altering the pathogen's ability to grow under that condition (Stuttmann et al. 2011). Meanwhile, valine is important amino acids for nitrogen balance in plants (Binder et al. 2007).
Besides sugars and amino acids, red rice also contains the amount of organic acid like succinic acid and fumaric acid and choline. Succinic acid is known as a mediator for energy production through TCA cycle (Satyanarayana and Radhakrishnan 1962). Meanwhile, fumaric together with glycerols, malate, citrate, succinate, malonate, and stearate will be accumulated during the oxidative burst process for producing $\mathrm{H}_{2} \mathrm{O}_{2}$ (Halliwell 1977). Subsequently, choline is known as a precursor of glycine betaine, metabolite which responsible for protecting plants from environmental stress (Sakamoto and Murata 2002).

Based on Figure 2, black rice has a much higher concentration of hydroxyl-L-proline and adenosine. HydroxyL-proline is important constituents of the plant cell, having a structural role in the primary cell wall (Ashford and Neuberger 1980) and adenosine is widely found in nature and plays an important role in biochemical processes, such as energy transfer (as adenosine triphosphate (ATP) and adenosine diphosphate (ADP)) (Heldt and Heldt 2005).

In fact, no study reported about metabolite profile differentiation between black rice and red rice cultivars in Yogyakarta. However, a similar study which had been done by Pramai et al. (2017) can be used as comparison. They used germinated pigmented rice from local cultivars in Thailand. Totally, they identified 34 metabolites using ${ }^{1} \mathrm{H}$ NMR. This difference in the number of metabolites is probably caused by some factors. First, the age of grain used was different. In this research, young grain (at the milky stage) was used as sample material. In this stage, probably the grains have less metabolites compare with ripening stage. Second, they used germinated pigmented rice and we did not. During the germination process, en- 


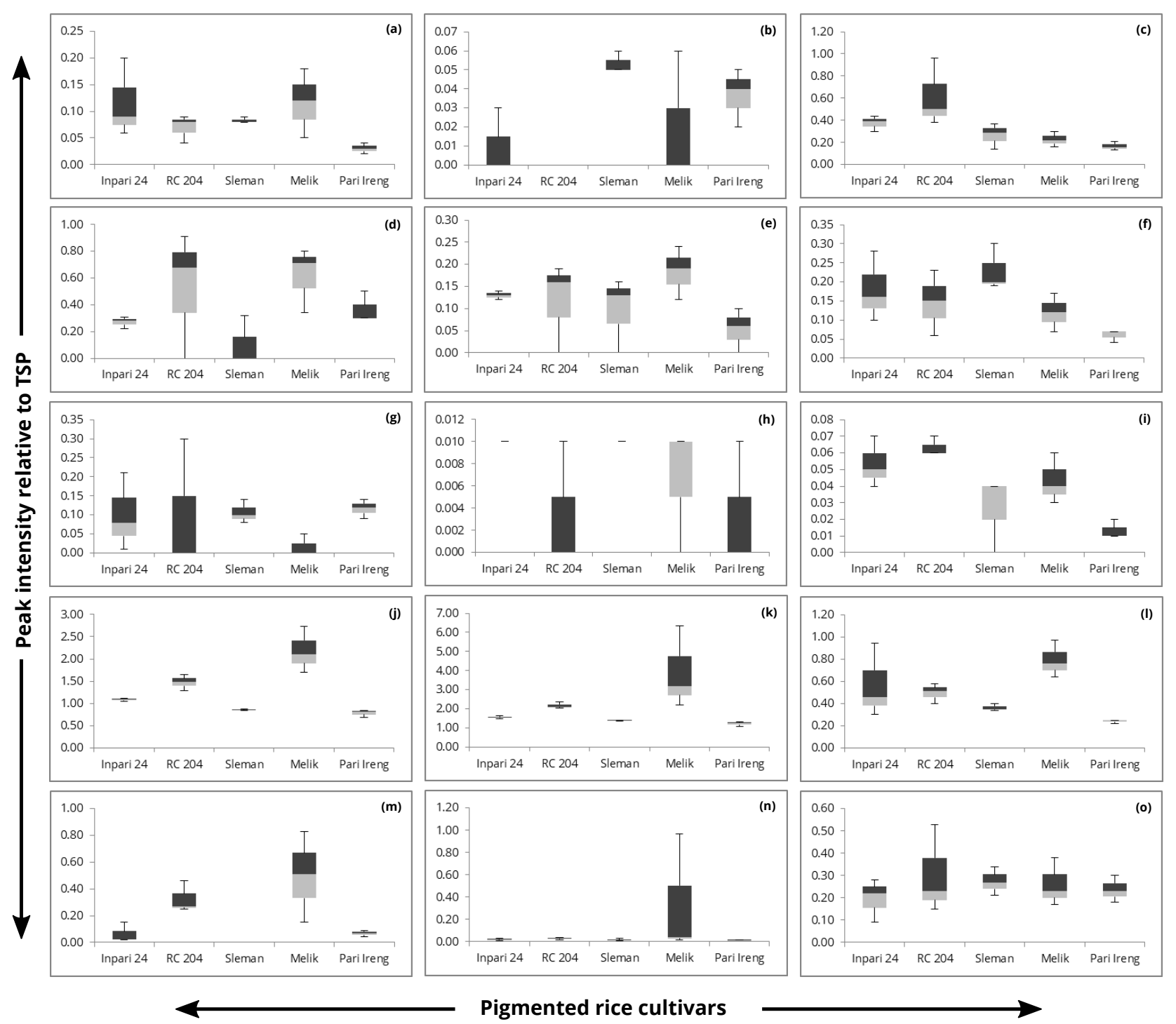

FIGURE 3 Quantitative expression of metabolites of each cultivars: (a) valine; (b) hydroxy-ı-proline; (c) alanine; (d) glutamate; (e) threonine; (f) acetate; (g) succinate; (h) formate; (i) fumarate; (j) a-glucose; (k) $\beta$-glucose; (I) galactinol; (m) raffinose; (n) adenosine; (o) choline.

dogenous hydrolytic enzymes are activated to break down starch, fibers, and proteins (Kim et al. 2012; Komatsuzaki et al. 2007). This process made much more metabolites could be read by NMR. The last, we believe that our results still have so many unidentified signals because of limitations of references. Some previous studies reported that there are metabolite differentiations between black rice and red rice (Yawadio et al. 2007; Frank et al. 2012; Na Jom et al. 2016; Huang and Lai 2016; Pramai et al. 2017), and our data show similar results with the previous studies mentioned.

\section{Conclusions}

Metabolomics using ${ }^{1} \mathrm{H}-\mathrm{NMR}$ analysis enabled the identification of metabolites responsible for variations between red rice and black rice, with 15 metabolites identified. There is a significant difference in metabolites concen- tration between red rice and black rice. The metabolites responsible for the separation of red rice and black rice are valine, threonine, alanine, glutamate, galactinol, $\beta$ glucose, $\alpha$-glucose, raffinose and fumaric acid.

\section{Acknowledgments}

This research supported by the funding from the Seed Fund for Research and Training (SFRT) Program of the Southeast Asian Regional Center for Graduate Study and Research in Agriculture (SEARCA) to TRN and DI.

\section{Authors' contributions}

DNW, FAS performed the field and laboratory works. DNW, FAS, TRN analyzed the data and wrote the manuscript. YAP, DI, TRN conceived and designed the study. All authors have read and approved the final version of the manuscript. 


\section{Competing interests}

The authors declare no competing interest.

\section{References}

Andoko A. 2012. Budi daya padi secara organik [Organic rice cultivation]. Jakarta: Penebar Swadaya.

Asamarai AM, Addis PB, Epley RJ, Krick TP. 1996. Wild rice hull antioxidants. J Agric Food Chem. 44(1):126130. doi:10.1021/jf940651c.

Ashford D, Neuberger A. 1980. 4-Hydroxyl-l-proline in plant glycoproteins: Where does it come from and what is it doing there? Trends Biochem Sci. 5(9):245248. doi:10.1016/S0968-0004(80)80813-9.

Binder S, Knill T, Schuster J. 2007. Branchedchain amino acid metabolism in higher plants. Physiol Plant. 129(1):68-78. doi:10.1111/j.13993054.2006.00800.x.

Bolouri-Moghaddam MR, Le Roy K, Xiang L, Rolland F, Van den Ende W. 2010. Sugar signalling and antioxidant network connections in plant cells: Sugar signalling and antioxidant networks in plants. FEBS J. 277(9):2022-2037. doi:10.1111/j.17424658.2010.07633.x.

Bylesjö M, Rantalainen M, Cloarec O, Nicholson JK, Holmes E, Trygg J. 2006. OPLS discriminant analysis: combining the strengths of PLS-DA and SIMCA classification. J Chemom. 20(8-10):341-351. doi:10.1002/cem.1006.

Chen Q, Ling W, Ma J, Mei J. 2000. [Effects of black and red rice on the formation of aortic plaques and blood lipids in rabbits]. Wei Sheng Yan Jiu [J Hyg Res.] 29(3):170-172.

Dai H, Xiao C, Liu H, Tang H. 2010. Combined NMR and LC-MS analysis reveals the metabonomic changes in Salvia miltiorrhiza Bunge induced by water depletion. J Proteome Res. 9(3):1460-1475. doi:10.1021/pr900995m.

Fan TWM. 1996. Metabolite profiling by one- and two-dimensional NMR analysis of complex mixtures. Prog Nucl Magn Reson Spectrosc. 28(2):161-219. doi:10.1016/0079-6565(95)01017-3.

Frank T, Reichardt B, Shu Q, Engel KH. 2012. Metabolite profiling of colored rice (Oryza sativa L.) grains. J Cereal Sci. 55(2):112-119. doi:10.1016/j.jcs.2011.09.009.

Gill SS, Tuteja N. 2010. Polyamines and abiotic stress tolerance in plants. Plant Signaling Behav. 5(1):2633. doi:10.4161/psb.5.1.10291.

Ginanjar E. 2016. Kajian ketahanan padi berpigmen (Oryza sativa L.) terhadap penyakit blas melalui pendekatan transkriptomik dan metabolomik [Transcriptomics and metabolomics study of pigmented rice (Oryza sativa L.) resistant to blast disease]. [Master's thesis]. [Yogyakarta, Indonesia]: Universitas Gadjah Mada.
Hall R, Beale M, Fiehn O, Hardy N, Sumner L, Bino R. 2002. Plant metabolomics: the missing link in functional genomics strategies. Plant Cell 14:1437-1440. doi:10.1105/tpc.140720.

Halliwell B. 1977. Generation of hydrogen peroxide, superoxide and hydroxyl radicals during the oxidation of dihydroxyfumaric acid by peroxidase. Biochem J. 163(3):441-448. doi:10.1042/bj1630441.

Heldt HW, Heldt F. 2004. Plant biochemistry. $2^{\text {nd }}$ edition. Academic Press.

Heldt HW, Heldt F. 2005. Plant biochemistry. $3^{\text {rd }}$ edition. Academic Press.

Herbers K, Meuwly P, Métraux JP, Sonnewald U. 1996. Salicylic acid-independent induction of pathogenesisrelated protein transcripts by sugars is dependent on leaf developmental stage. FEBS Lett. 397(2-3):239244. doi:10.1016/s0014-5793(96)01183-0.

Hofmann J, El Ashry AEN, Anwar S, Erban A, Kopka J, Grundler F. 2010. Metabolic profiling reveals local and systemic responses of host plants to nematode parasitism. Plant J. 62(6):1058-1071. doi:10.1111/j.1365313X.2010.04217.x.

Huang T, Jander G, de Vos M. 2011. Non-protein amino acids in plant defense against insect herbivores: representative cases and opportunities for further functional analysis. Phytochemistry 72(13):1531-1537. doi:10.1016/j.phytochem.2011.03.019.

Huang YP, Lai HM. 2016. Bioactive compounds and antioxidative activity of colored rice bran. J Food Drug Anal. 24(3):564-574. doi:10.1016/j.jfda.2016.01.004.

Hyun JW, Chung HS. 2004. Cyanidin and malvidin from Oryza sativa cv. Heugjinjubyeo mediate cytotoxicity against human monocytic leukemia cells by arrest of $\mathrm{G}(2) / \mathrm{M}$ phase and induction of apoptosis. J Agric Food Chem. 52(8):2213-2217. doi:10.1021/jf030370h.

Ichikawa H, Ichiyanagi T, Xu B, Yoshii Y, Nakajima M, Konishi T. 2001. Antioxidant activity of anthocyanin extract from purple black rice. J Med Food. 4(4):211218. doi:10.1089/10966200152744481.

Jones OAH, Maguire ML, Griffin JL, Jung YH, Shibato J, Rakwal R, Agrawal GK, Jwa NS. 2011. Using metabolic profiling to assess plant-pathogen interactions: an example using rice (Oryza sativa) and the blast pathogen Magnaporthe grisea. Eur J Plant Pathol. 129(4):539-554. doi:10.1007/s10658-0109718-6.

Kim HK, Choi YH, Verpoorte R. 2010. NMR-based metabolomic analysis of plants. Nat Protoc. 5(3):536549. doi:10.1038/nprot.2009.237.

Kim HY, Hwang IG, Kim TM, Woo KS, Park DS, Kim JH, Kim DJ, Lee J, Lee YR, Jeong HS. 2012. Chemical and functional components in different parts of rough rice (Oryza sativa L.) before and 
after germination. Food Chem. 134(1):288-293. doi:10.1016/j.foodchem.2012.02.138.

Kim MS, Cho SM, Kang EY, Im YJ, Hwangbo H, Kim YC, Ryu CM, Yang KY, Chung GC, Cho BH. 2008. Galactinol is a signaling component of the induced systemic resistance caused by Pseudomonas chlororaphis O6 root colonization. Mol Plant Microbe Interact. 21(12):1643-1653. doi:10.1094/mpmi-21-121643.

Koch K. 2004. Sucrose metabolism: regulatory mechanisms and pivotal roles in sugar sensing and plant development. Curr Opin Plant Biol. 7(3):235-246. doi:10.1016/j.pbi.2004.03.014.

Komatsuzaki N, Tsukahara K, Toyoshima H, Suzuki T, Shimizu N, Kimura T. 2007. Effect of soaking and gaseous treatment on GABA content in germinated brown rice. J Food Eng. 78(2):556-560. doi:10.1016/j.jfoodeng.2005.10.036.

Kristamtini, Purwaningsih H. 2009. Potensi pengembangan beras merah sebagai plasma nutfah Yogyakarta [Development potential of red rice as Yogyakarta's germplas]. Jurnal Litbang Pertanian 28(3):88-95.

Kusano M, Yang Z, Okazaki Y, Nakabayashi R, Fukushima A, Saito K. 2015. Using metabolomic approaches to explore chemical diversity in rice. Mol Plant 8(1):58-67. doi:10.1016/j.molp.2014.11.010.

Ling WH, Cheng QX, Ma J, Wang T. 2001. Red and black rice decrease atherosclerotic plaque formation and increase antioxidant status in rabbits. J Nutr. 131(5):1421-1426.

Ling WH, Wang LL, Ma J. 2002. Supplementation of the black rice outer layer fraction to rabbits decreases atherosclerotic plaque formation and increases antioxidant status. J Nutr. 132(1):20-26.

Liu C, Du B, Hao F, Lei H, Wan Q, He G, Wang Y, Tang H. 2017. Dynamic metabolic responses of brown planthoppers towards susceptible and resistant rice plants. Plant Biotechnol J. 15(10):1346-1357. doi:10.1111/pbi.12721.

Matsumoto H, Nakamura Y, Tachibanaki S, Kawamura S, Hirayama M. 2003. Stimulatory effect of cyanidin 3-glycosides on the regeneration of rhodopsin. J Agric Food Chem. 51(12):3560-3563. doi:10.1021/jf034132y.

Mingwei Z, Baojiang G, Ruifen Z, Jianwei C, Zhencheng W, Zhihong X, Yan Z, Xiaojun T. 2006. Separation, purification and identification of antioxidant compositions in black rice. Agric Sci China 6(5):431-440. doi:10.1016/s1671-2927(06)60073-4.

Moreno YS, Sánchez GS, Hernández DR, Lobato NR. 2005. Characterization of anthocyanin extracts from maize kernels. J Chromatogr Sci 43(9):483-487.

Morkunas I, Marczak Ł, Stachowiak J, Stobiecki M. 2005. Sucrose-induced lupine defense against Fusarium oxysporum: sucrose-stimulated accumulation of isoflavonoids as a defense response of lupine to Fusarium oxysporum. Plant Physiol Biochem. 43(4):363373. doi:10.1016/j.plaphy.2005.02.011.

Na Jom K, Lorjaroenphon Y, Udompijitkul P. 2016. Differentiation of four varieties of germinating Thai colored indica rice (Oryza sativa l.) by metabolite profiling. Food Sci Technol Res. 22(1):65-73. doi:10.3136/fstr.22.65.

Nam MH, Bang E, Kwon TY, Kim Y, Kim EH, Cho K, Park WJ, Kim BG, Yoon IS. 2015. Metabolite profiling of diverse rice germplasm and identification of conserved metabolic markers of rice roots in response to long-term mild salinity stress. Int J Mol Sci. 16(9):21959-21974. doi:10.3390/ijms160921959.

Nam SH, Choi SP, Kang MY, Koh HJ, Kozukue N, Friedman M. 2006. Antioxidative activities of bran extracts from twenty one pigmented rice cultivars. Food Chem. 94(4):613-620. doi:10.1016/j.foodchem.2004.12.010.

Nuringtyas TR, Choi YH, Verpoorte R, Klinkhamer PG, Leiss KA. 2012. Differential tissue distribution of metabolites in Jacobaea vulgaris, Jacobaea aquatica and their crosses. Phytochemistry 78:89-97. doi:10.1016/j.phytochem.2012.03.011.

Pramai P, Abdul Hamid NA, Mediani A, Maulidiani M, Abas F, Jiamyangyuen S. 2017. Metabolite profiling, antioxidant, and $\alpha$-glucosidase inhibitory activities of germinated rice: nuclear-magnetic-resonancebased metabolomics study. J Food Drug Anal. doi:10.1016/j.jfda.2016.11.023.

Rolland F, Baena-Gonzalez E, Sheen J. 2006. Sugar sensing and signaling in plants: conserved and novel mechanisms. Annu Rev Plant Biol. 57(1):675-709. doi:10.1146/annurev.arplant.57.032905.105441.

Sakamoto A, Murata N. 2002. The role of glycine betaine in the protection of plants from stress: clues from transgenic plants. Plant Cell Environ. 25(2):163-171. doi:10.1046/j.0016-8025.2001.00790.x.

Satyanarayana T, Radhakrishnan AN. 1962. Biosynthesis of valine and isoleucine in plants. Biochim Biophys Acta 56:197-199. doi:10.1016/0006-3002(62)905541.

Slamet-Loedin I, Rahayu W, Hutajulu S, Wibowo J. 1997. Penggunaan dua strain Agrobacterium tumefaciens supervirulen untuk ko-kultivasi tanaman padi kultivar Cisadane dan Rojolele [The use of two strains Agrobacterium tumafaciens supervirulen for co-cultivation of rice cultivars Cisadane and Rojolele]. Surabaya: Indonesian Biotechnological Society Seminar.

Steinbrenner AD, Gómez S, Osorio S, Fernie AR, Orians CM. 2011. Herbivore-induced changes in tomato (Solanum lycopersicum) primary metabolism: a whole plant perspective. J Chem Ecol. 37(12):12941303. doi:10.1007/s10886-011-0042-1. 
Stuttmann J, Hubberten HM, Rietz S, Kaur J, Muskett P, Guerois R, Bednarek P, Hoefgen R, Parker JE. 2011. Perturbation of Arabidopsis amino acid metabolism causes incompatibility with the adapted biotrophic pathogen Hyaloperonospora arabidopsidis. Plant Cell 23(7):2788-2803. doi:10.1105/tpc.111.087684.

Tananuwong K, Tewaruth W. 2010. Extraction and application of antioxidants from black glutinous rice. LWT - Food Scie Technol. 43(3):476-481. doi:10.1016/j.lwt.2009.09.014.

Uawisetwathana U, Graham SF, Kamolsukyunyong W, Sukhaket W, Klanchui A, Toojinda T, Vanavichit A, Karoonuthaisiri N, Elliott CT. 2015. Quantitative 1h NMR metabolome profiling of Thai Jasmine rice (Oryza sativa) reveals primary metabolic response during brown planthopper infestation. Metabolomics 11(6):1640-1655. doi:10.1007/s11306-015-0817-4.

Wang Q, Han PH, Zhang MW, Xia M, Zhu HL, Ma J, Hou MJ, Tang ZH, Ling WH. 2007. Supplementation of black rice pigment fraction improves antioxidant and anti-inflammatory status in patients with coronary heart disease. Asia Pac J Clin Nutr. 16(S1):295-301.

Westerhuis JA, Velzen EJJv, Hoefsloot HCJ, Smilde AK. 2010. Multivariate paired data analysis: multilevel PLSDA versus OPLSDA. Metabolomics 6(1):119128. doi:10.1007/s11306-009-0185-z.

Wijaya D. 2017. Kajian ketahanan padi berpigmen (Oryza sativa L.) terhadap walang sangit (Leptocorisa oratorius) berbasis NMR metabolomik [NMR metabolomics study on rice ear bug (Leptocorisa oratorius) resistance in pigmented rice]. [Master's thesis]. [Yogyakarta, Indonesia]: Universitas Gadjah Mada.

Xu F, Wang E. 1989. The effects of pigmented rice on hemoglobin regeneration in anemic rats. Acta Nutr Sin. 11:120-125.

Yawadio R, Tanimori S, Morita N. 2007. Identification of phenolic compounds isolated from pigmented rices and their aldose reductase inhibitory activities. Food Chem. 101(4):1616-1625. doi:10.1016/j.foodchem.2006.04.016.

Yoshinaga K, Takahashi K, Yoshizawa K. 1986. Liqueur making using pigments of red rice. J Soc Brew, Jpn. 81(5):337-340. doi:10.6013/jbrewsocjapan1915.81.337. 